\title{
Building a Temporal Theatre Community in the Production of ATLAS - LJUBLJANA
}

Tomaž Krpič

\begin{abstract}
Abstrakt
Autor analyzuje slovinskou inscenaci ATLAS od portugalských režisérů a performerů Any Borralho a Joãa Galante a ukazuje proces transformace, kterým diváci predstavení procházeli. Autor popisuje, jak byla jejich těla $v$ průběhu představení přeměněna na autobiografická těla prostřednictvím sdílení společného času a prostoru v prostředí vzájemné důvěry a pocitu bezpečí navozeného v dočasné performanční komunitě. Své záběry autor formuluje na základě rozhovorů s několika účastníky představení a svých vlastních pozorování provedených $\checkmark$ průběhu představení inscenace ATLAS - LJUBLJANA.
\end{abstract}

\section{Klíčová slova}

inscenace hry ATLAS - LJUBLJANA; participace; autobiografické tělo; dočasná divadelní komunita

\begin{abstract}
The author analyses the Slovenian production of ATLAS, staged by Ana Borralho and João Galante, who are both performers and theatre directors from Potugal. The author shows that the participants went through a process of transforming their bodies into autobiographical bodies and this transformation was performed by 'exchanging' time and space through which interpersonal confidence and safety was achieved within a temporal performing community. These findings are based on interviews the author conducted with several participants and his own observations made during his participation in ATLAS - LJUBLJANA.
\end{abstract}

\section{Keywords}

ATLAS - LJUBLJANA; participation; autobiographical body; temporal theatre community 


\section{Introduction}

ATLAS is an art project created by Ana Borralho and João Galante, both of whom are theatre directors and performers from Portugal. Borralho and Galante are prolific artists who in the past have stirred public opinion with provocative political interventions in the form of art performances or installations. The project consists of a series of performances staged in many European cities and Montreal from 2012 to 2017.

Each production within the ATLAS series is created according to the same principles and has the same structure. The project is a critical reflection on the current economic, social and political situation in Europe which is seen by many as deprived and unjust. The piece was inspired by the Greek mythological story of Atlas, who was condemned to stand with Earth and the Heavens on his shoulders. Another inspiration was the nursery rhyme: 'If one elephant disturbs many people, two elephants disturb them much more; if two elephants disturb many people, three elephants disturb them much more...'

In this article I refer to the production of the performance that was staged in the Slovenian capital city of Ljubljana on 24 August 2013. The performance was a part of the annual Mladi levi festival, ${ }^{1}$ organized by Bunker - Stara elektrarna (the Old Power Station) which is a non-profit organization for the realization and organization of cultural events. Rehearsals took place on stage in Bunker - Stara elektrarna and in a small hall in the nearby youth hostel Dijaški dom Tabor. Originally the event should have been performed in an open air venue in front of the Slovene Ethnographic Museum, but due to the uncertain weather conditions it was performed in the main hall of the cultural centre Španski borci, not far away from the initial location.

$A T L A S$ is a performance for the participants. If someone who is an actor by profession appears amongst the participants on stage, he or she is not there to impersonate a specific role, but is a 'representative' of him- or herself. The participants in ATLAS are neither like some spectators who join the actors on stage. Firstly, the stage does not include any actors or performers in the traditional sense, so there is nobody to join to. Secondly, he or she was never a spectator in the first place, because he or she joined the performance long before it was actually performed on stage. Anyone who is the participant in ATLAS took an active role in the shift from the art for spectators to the art for participants (BERTINETTO 2010: 222). The participants for ATLAS $L J U B L J A N A$ were recruited according to the 'snow ball' and 'friendship or acquaintance' principles.

Each production of ATLAS starts roughly a week before the performance takes place. It takes about a week of preparations before the performance is ready for the audience. Even though the performance has a relatively plain dramaturgy, it takes time for an average individual to transform into a participant. With the aid of participants, the

1 The international festival Mladi Levi has been bringing the most current stage performances from all over the world to Ljubljana, Slovenia at the end of every summer since 1998. It bears the mark of a demanding artistic profile, placed within the arena of contemporary progressive theatre and takes pride in its reputation for discovering young talent. 
creators develop distinct features that are related to the 'local' economic, political and social environment. One of the major elements that is developed during the preparation week is establishing an topic or message that they want to deliver to the audience. They try to establish what the participants consider to be the most salient current social issue. For ATLAS - LJUBLJANA, that issue was the high level of youth unemployment and the sense that neither the government nor politicians were doing anything to improve the situation.

Once that issue had been established, they came up with a short sentence that was linked to it within the Slovenian context. The sentence had the same structure as the previously mentioned nursery rhyme: 'If [sequential number of the participant] [adjective] [professional status or aspiration of the participant] disturb many people, then [sequential number of the participant plus one] [adjective] [professional status or aspiration of the participant] disturb them much more!' This was the basic structure each participant used in the construction of his own statement which reflected her or his professional status or aspirations. However, not every participant had merely a simple, short statement to perform. A few participants were allowed to perform longer speeches that were linked to certain moments in the performance. At a certain moment of the performance all participants who are on stage simultaneously addressed the audience. They told their own personal stories, which were not necessary strictly related to the performance's message. They spoke to each other, creating a cacophonic sound consisting of numerous individual stories that reminded the audiences that there were many voices that wish to be heard within society.

There were a few basic principles that the participants of ATLAS - LJUBLJANA had to apply during the performance. One of the most important principles was the participants' sequential entrance onto the stage. One by one the participants joined the ones already on stage, until all participants were on stage together. The participants formed a line, which grew gradually, stretching from one side of the stage to another, moving in waves, like on a catwalk, from the back of the stage to its front. Every time the line reached the back of the stage and turned towards the audience, the line was joined by another participant. The line accompanied the last participant and joined him in his walk towards the front of the stage. Once all participants arrived on stage and had performed the last walk forward, they ended the performance by walking off stage and through the audience.

The participants in ATLAS - LJUBLJANA believe that they helped build a temporal aesthetic community with the physical presence of their biographical bodies. This was established by claiming and giving space and time and using their biographical bodies to establish a safe atmosphere filled with confidence, that has limited and modest effects even beyond the space and time frame of ATLAS - LJUBLJANA.

The article is based on the interviews I conducted with several participants and the observations I made during my engagement as one of the participants in ATLAS LJUBLJANA. The interviews were not structured, although I used several pre-prepared questions as a starting point. The form of my interviews ranged from a classic interview to an informal debate. It was my intention to make an empirical entry into the research 
on participation in theatre by using the case of ATLAS - LJUBLJANA as an example, and I did not make any presumptions on the outcome of the interviews. My identity as an independent researcher of post-dramatic theatre and performance and reasons for participating in ATLAS - LJUBLJANA were both evident and were made clear to all of the participants, either during introduction at the initial meeting or during later conversations and interviews. However, to a large extent this article is structured around the answers I received from my respondents who accentuated the importance of perceiving their bodies, the process of giving and claiming space and time to and from each other and establishing a sense of confidence and safety that enabled them to develop a community sentiment. No special method was used for picking out those participants who were willing to take part in my small scale research on participation in theatre. Subject selection was random. ${ }^{2}$

\section{Talking Auto-biographical Body}

The physical action of the participants was simple. It did not require great physical skill or effort to take part in the production. Almost anyone capable of moving (not necessary walking) across the stage, stopping close to the edge of the stage and uttering a short personal statement in front of an audience met the criteria to become a participant in this performance.

Nevertheless, the creators of the performance put a lot of effort into the physical conditioning of the participants. They understand the participants' physical preparation as a positive precondition necessary for a good performance. However, the goal of the physical engagement during rehearsals was not to improve the physical condition of the participants, but to secure their psychological condition. To a great extent, the performance followed Augusto Boal's four steps of aesthetics in the theatre of the oppressed: from the process of the participant knowing his or her body and making it a means of expression to understanding theatre as a special form of language and discourse (BOAL 1979: 102-120).

One of the participants positively evaluated the physical engagement during the preparation week, depicting it as a process in which one 'felt like one's rediscovering one's own body..., ${ }^{3}$ whereas another participant mentioned the positive outcomes of 'investing' into the performing body: 'I felt communicative and extraverted, and I placed greater importance on body language than I did outside the theatre settings. It became natural for me to hug somebody during rehearsals.' Through the production of the autobiographical body, the participant's body was gradually transformed into a performing body. According to Meehan (2013: 48) the autobiographical body is a transitional object between the subject and object. The development of autobiographical bodies for ATLAS - LJUBLJANA allowed the participants to both express

2 For that, I am deeply grateful to them.

3 All quotations are taken from the interviews conducted with the participants during ATLAS - LJUBLJANA. 


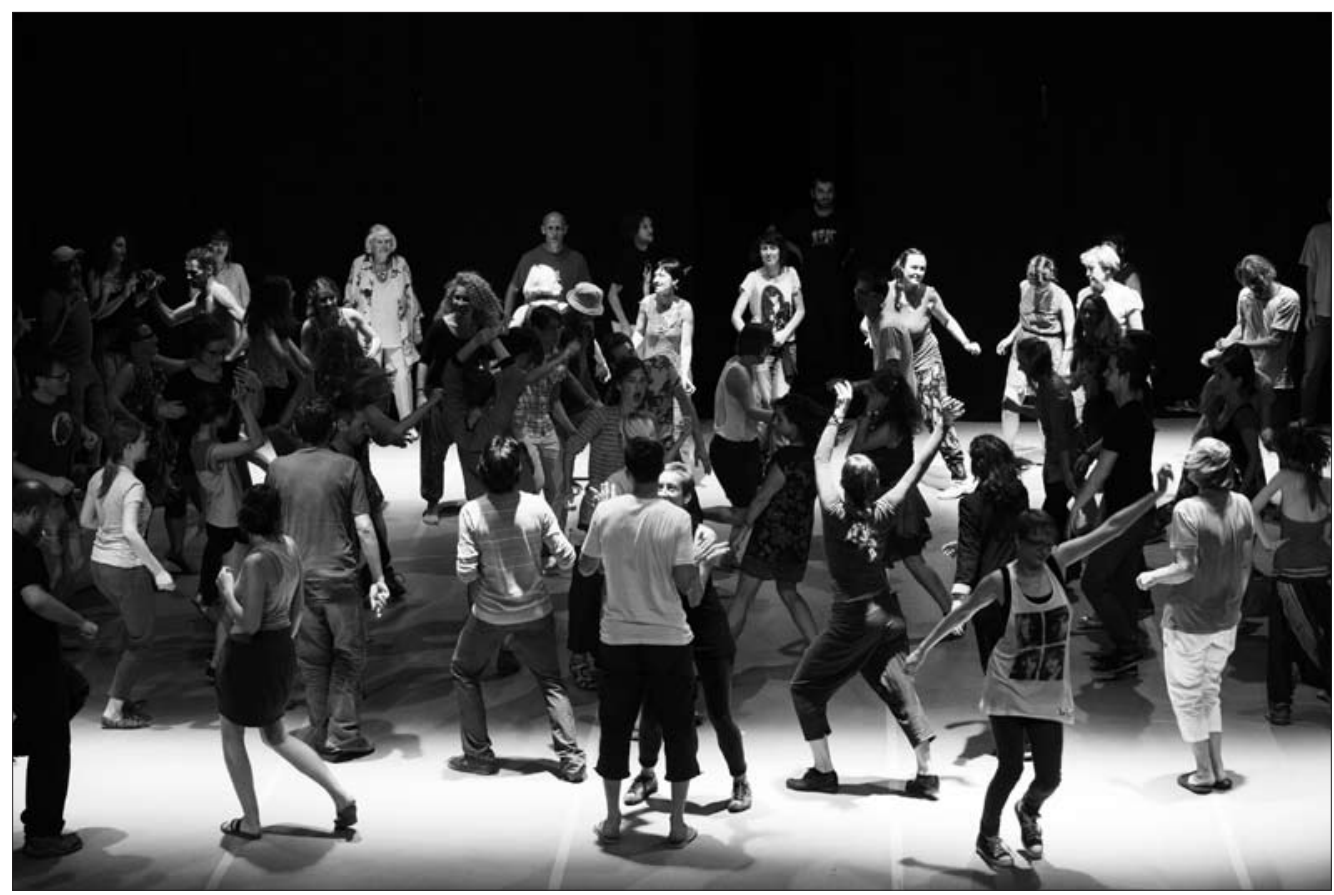

Fig. 1: Images from the rehearsals. Photo Nada Žgank.

their individual feelings and thoughts with regard to their professional experiences and their longing for a better (professional) life and it enabled them to reach beyond their private lives and build a temporal community within the theatre.

During the preparations for the final performance on stage, the participants went through several physical rehearsals, which started with a personal introduction, followed by a warm up session which consisted of basic bodily movements, such as walking, running, jumping, or dancing in order to regain bodily awareness, and ended with a set of rehearsals that were used to establish a physical connection between the participants (e.g. running randomly around touching each other's nose etc).

In Applying Performance, Nicola Shaughnessy wrote that in biographical performances, the self is source and the body speaks [...]' and such performance ' $[. .$.$] is not$ a result of mimesis, but emerges from the spectators felt responses to the experiences of liveliness, being in a shared space and being affected by the haptic, visceral qualities of work which can "touch" them (sometimes literarily)' (SHAUGHNESSY 2012: 47). Although Shaughnessy accentuated the relation between theatre production and the spectator's cognitive reaction to it, the above quotation can represent a starting point for the further development of an explanatory model of the participant's relation between their inner cognitive and emotional life and the external 'acting' on stage. ATLAS - LJUBLJANA shows that the participants can produce visceral qualities while taking part on stage. While standing and speaking on stage, they are using their own bodies as a means of interpersonal communication to speak about their 'visceral qual- 
ity' of being onstage. In addition, the line of individuals represents a mechanism with which it is possible to deliver one's knowledge about one's professional position in the social, cultural, economic and political context of Slovenian society.

The participants used little traditional body language to communicate with the audience throughout most of the performance. The participants also used spoken language. Each participant who joined the group of participants on stage uttered a biographical line which revealed his or her professional experiences by the application of the nursery rhyme. The individual lines were composed of two parts, the first part beginning with: 'If [numberof participant] [adjective] [profession] disturb many people' and ending with (in unison with the remaining participants on stage) 'then [number +1 ] [adjective] [profession] disturb them much more!' Each individual was allowed to freely create biographical line as long as it stayed within the frame of the nursery rhyme. The hope of the creators and participants is that the spoken lines send a strong impulse that politicians will be disturbed by the messages and will do something to help people in Slovenia with their problem of professional status and unemployment.

\section{Giving and Claiming Space and Time}

To a large degree, ATLAS is about participants giving and claiming shared time and space. The time dimension has a double structure within the performance. On one hand, the participants share their personal time during the preparation for the final performance. By sharing their individual time, they construct a distinct community time: a rhythm of collective rehearsals and the final production. On the other hand, every participant has their own public moment when the spotlights focus fully on their own autobiographical body - a sort of a time bracket - when the other participants 'step aside' and give the autobiographical body the privilege of personal time in public. This moment occurs when it is the individual participant's turn to come from the backstage and deliver their autobiographical line. It is entirely down to them to choose how long this will take, and the remaining participants on stage have to pay them respect and provide support by mimicking their bodily behaviour and giving them all the time they need for their performance. This is the time devoted to them within the timeframe of the ATLAS performance.

While time is sometimes hard to grasp in theatre, space is evident; it is primarily defined by the other participants' autobiographical bodies. However, while the participants can literally share the same time together, they, nevertheless, cannot share the same space in the same manner. Such an attempt would be merely swarming for more space. Having someone encroach on one's 'body space' is a negative experience whereas giving up space on behalf of someone else - perhaps someone who does not have enough of it - is considered to be a gesture of goodwill or an act showing respect for their rights.

According to the participants, ATLAS - LJUBLJANA 'is a performance that gives you space'. When the line of participants reached the back of the stage, it opened up in 


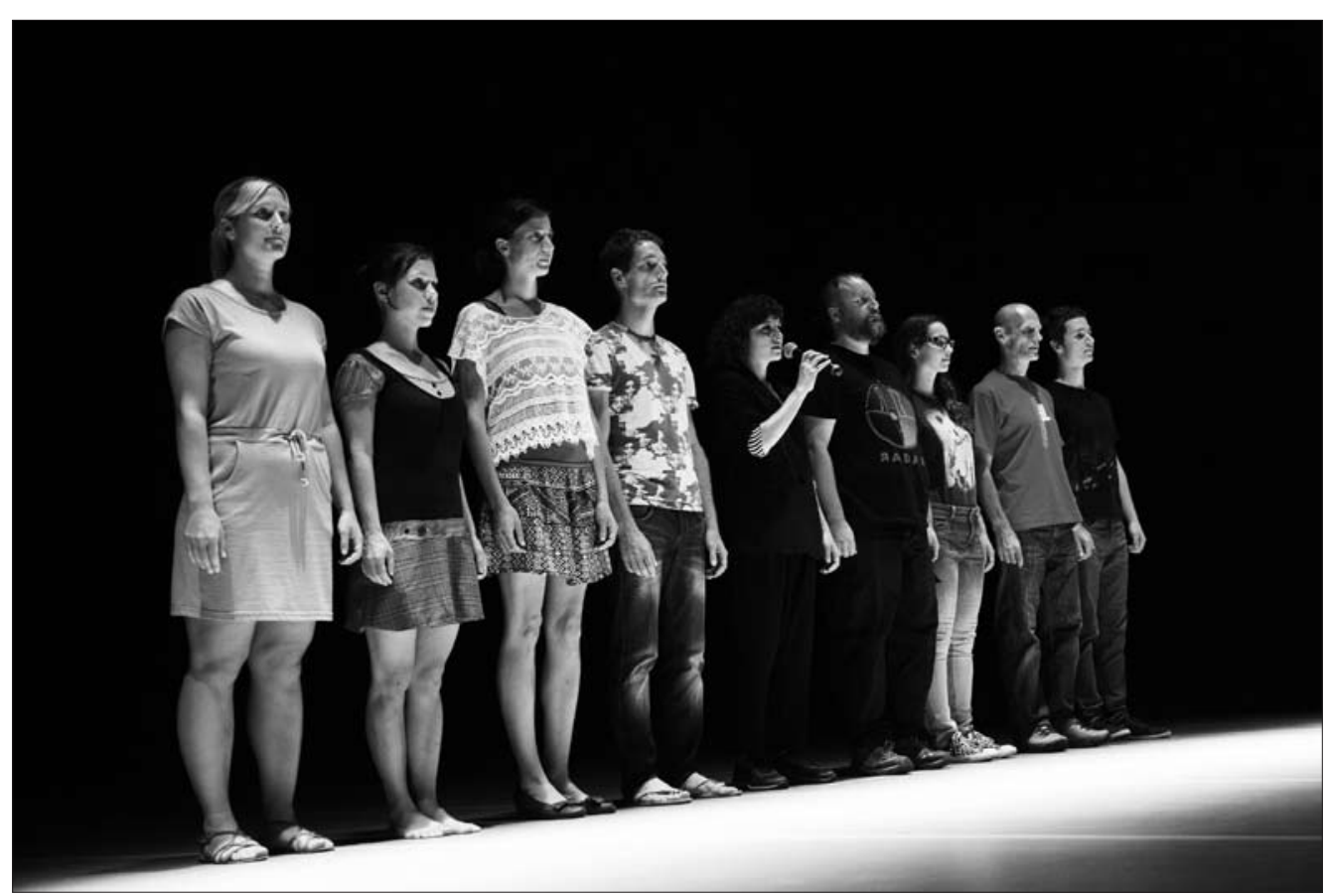

Fig. 2: ATLAS - LJUBLJANA, 24 August 2013, Španski borci, Ljubljana. Photo Nada Žgank.

the middle and space was offered to the new participant who joined the line. This was 'how the doors were opened for every participant'. So, giving space to someone was not merely a metaphor; it was a physical act. Then the line walked towards the foreground of the stage again, following the rhythm of the newcomer, the so-called 'queen' or 'king'. The rest of the participants on stage attempted to imitate the queen's or king's body movements (speed of walking, posture and gestures) as well as the rhythm and melody of their spoken words. Their role ended once the line of participants reached the back of the stage again, and a new participant joined in.

Similar to the process of transforming individuals into participants, reaching an equilibrium between giving and receiving time and space was a fragile and uncertain process in the preparation week. ${ }^{4}$ As one of the participants said in one of our occasional short conversations during a rehearsal break: 'If somewhere someone gives you space, an opening, you should "fill it". Not merely point to the place which should be given to you ... Go with the flow'. If a participant failed to claim space with their autobiographical body, the space might not have been given to him or her after all.

4 During the preparation week, certain individuals came with the wish to join the group, but in the end they gave up due to various reasons and failed to participate in the performance ATLAS - LJUBLJANA. 


\section{Building Safety and Confidence}

The progressive addition of autobiographical bodies on stage, giving and receiving space and time, constructed interpersonal confidence and gave a feeling of security to the participants' autobiographical bodies. As one of the participants noticed, a great deal of credit should be given to the creators of ATLAS, who included mechanisms that build a certain level of safety and confidence in the participants:

The calm manner used by the theatre directors made me feel I could trust them. [...] They didn't forget anyone - they took care of us all, no matter what. I was totally relaxed due to the feeling of trust. [...] I never lost the feeling of trust.

Similarly, another participant said she 'was really surprised how people would open up and tell some very personal stories.' The experience of being a part of ATLAS LJUBLJANA placed them in a new situation, in which everyday relations between people could be challenged and seen from a different perspective. Eviatar Zerubavel wrote that during a lifetime an individual painstakingly learns how to successfully balance between occasional destruction, reconstruction and constant maintenance of her or his own individual cognitive and emotional structure in the context of society, culture, political and professional system or as a member of a distinct community. The individual's confidence and sense of security depend heavily on one's creativity in the search for and maintenance of the equilibrium every time the relationship between destruction and construction is jeopardized or revised (ZERUBAVEL 1991: 115-122).

$A T L A S$ - LJUBLJANA was a sort of a temporal 'theatre mechanism', the intention of which was to create 'social conditions' in which the participants - while building their autobiographical bodies and sharing time and space - temporally deconstructed an old rigid social structure and reconstructed a temporal and locally limited new one. This established safety and confidence. It gave 74 people the opportunity to speak about their personal issues and visions of their professional statuses and the way this influences their lives. They were given the opportunity to take a modest but fair part in an attempt to change the structure in which they believe their lives and bodies have been unjustifiably trapped by a neoliberal economy. People can destroy the rigid social and economic structure by using the mechanism of fuzziness engulfed in theatre as a mechanism with which a more flexible and justifiable social and professional structure can be achieved. In the example of ATLAS, the creation of the participants' autobiographical bodies was partially 'pre-packaged' in a structure given to the participants by its creators, Borralho and Galante; however, one must also keep in mind that this also held true for their feeling of security. 


\section{Establishing a Temporal Theatre Community}

Any art form presupposes the existence of an art community consisting of those who produce art and those who find meaning in its consummation. Theatre is no exception. The idea of community is deeply embedded in the structure of theatre (SHEVTSOVA 1989: 23-35; BLAU 1990: 10; NICHOLSON 2005: 83-86). The effects of the theatre community that was built during ATLAS - LJUBLJANA stretched mildly beyond the time and spatial limitations of the project. The participants' recognition that the aim and meaning of the project 'should be [...] found in building communal consciousness or in the construction of a deeper relationship between the participants' and that any 'coincidental relation between certain participants should be exceptional' was rather strong.

The definition of a theatre community is a rather open concept; none of the available definitions can entirely explain the phenomenon. However, I believe that the following elements are necessary in order to form a theatre community: a) a group of participants: spectators, actors, performers, dancers and similar; b) a number of shared theatre regulations that define the relations between the participants; c) a community sentiment of belonging together; d) non-deliberate construction; e) wider goals towards which the theatre community strives; f) a locality in which the theatre community is found; and g) relative permanency.

ATLAS - LJUBLJANA included 74 participants, amongst which we could find the initial creators of the performance and the Bunker - Stara elektrarna crew, who helped in the organization and who were considered members of the temporal theatre community. During the preparation week the participants went through the process of developing their autobiographical bodies. In order to become an autobiographical body, every participant needed to 'accept' two different types of shared regulations that enabled her or him to build a relationship with the other participants' autobiographical bodies on stage. One type of regulations stemmed from the content of $A T$ $L A S-L J U B L J A N A$. One such regulation, for instance, was the rule that one needs to offer someone who enters the stage enough space to perform his role as the 'queen' or 'king' and to escort their autobiographical body across the stage. In addition, the structure and the course of the performance were regulated, as they were given to the participants in advance. The regulations were given to the participants in oral form and through bodily gestures and movements shown by Catarina Goncalves and Tiago Gandra, Borralho's and Galante's assistants. The second type of regulations used in the construction of the relations between the autobiographical bodies in theatre were the ones the participants 'brought' with them from their lives and were not developed for the purpose of theatre in general or ATLAS - LJUBLJANA in particular. These regulations were the norms and values of the broader community within which the temporal theatre community was embedded, in our case the Slovenian society; the participant's longing for a higher level of social security and professional dignity can be considered as an external implicit regulation that was established before they entered the project. 
The participants within the theatre community ATLAS - LJUBLJANA developed a certain common sentiment. To a great extent their sentiment stemmed from the shared perception of the situation in Slovenia as regards to their professional expectations and future development. This sentiment of sharing a distinct social and economic environment was not deliberately or directly constructed alongside the development of ATLAS - LJUBLJANA, however, it gradually increased and strengthened from the day the participants first met to the day of their final public performance. The participants' common sentiment was also partially supported by the collective development of similar autobiographical bodies and the introduction of similar visceral qualities, which gave them a feeling of safety and confidence.

Perhaps the most intriguing question related to the construction of the temporal theatre community is whether the participants of ATLAS - LJUBLJANA constructed the theatre community deliberately. As the participants volunteered to take part in the performance and thus accepted the role of temporal performers, it is safe to assume that they did not join the performance with the intention of building a temporal theatre community. Many of them did not even know precisely what it was all about before they joined the group of participants at their first preparation meeting. At first, their expectations and feelings as regards their role in the production were vague and hazy, and propelled by certain anxiousness. However, it was clear that those who decided to play a part in the project gradually became members of a temporal and loosely integrated theatre community. Their knowledge as regards the existence of a theatre community, their social bonds with other participants and common sentiment increased over time. The same can be said for the wider goals towards which the theatre community consisting of 74 autobiographical performing bodies strived. The broader shared goals included improved conditions for the development of the individual's professional status and, as a consequence, a prosperous personal life. These elements led to a rather high empathic relation between the participants.

To a certain degree the locality in which this theatre community was established is important as this particular theatre production is only one in a sequence of several ATLAS productions. The 'scattered' character of the ATLAS art project signifies the geographical and timely connections, the unified nature and the omnipresence of the neoliberal economy in modern European society. It is an individualized society, in which people have to fight on a daily basis if they wish to secure a future for their vulnerable bodies.

It is clear that ATLAS - LJUBLJANA did not establish a lasting theatre community. However, its effects on the participants have modest long-lasting consequences. The participants do not maintain professional contact once the performance is brought to an end, since they were not brought together by the use of professional standards applied in theatre. The spectators viewed their autobiographical performing bodies as temporal. However, the Slovenian theatre environment is very small. Because the participants for ATLAS - LJUBLJANA were recruited according to the 'snow ball' and 'friendship or acquaintance' principles, some participants knew each another or were even friends or, perhaps, at least acquaintances even before the production of the 
performance ATLAS - LJUBLJANA started. However, some of the participants who were not friends or acquaintances before the production started remained in contact through social networks or by simply bumping into each other at various performances even after the production had ended.

\section{Conclusions}

In their book on the phenomenon of missing and overlooked human bodies, Casper and Moore (2009) stated that socially and politically 'invisible' bodies can struggle to become visible to others. The gap of invisibility can be overcome by the social agency of invisible people and their acknowledgement by those who look. The difference between visibility and invisibility is the difference between legitimacy, consideration, and implementation of human rights on one hand, and illegitimacy, obscurity and exploitation on the other. ATLAS - LJUBLJANA is a story about the 'invisible' and 'overlooked' bodies of individuals that struggle to become visible during the one week preparation for the final act by transforming into autobiographical performing bodies. In his book Theatre, Body and Pleasure Simon Shepherd (2006: 1) describes this process: 'Theatre is a practice in which societies negotiate about what the body is and means.' This transformation and negotiation of the participants' bodies was possible due to the process of claiming and giving space and time to each other which gave the participants a certain level of safety and confidence. One of the participants stated that 'the play gives the performer a feeling that her or his opinion matters and that she or he is an active member of society, while the play reminds the spectator of reality, something we often forget and something that stimulates her or him to become active beyond passive observation.' The participants in ATLAS - LJUBLJANA thus built a temporal theatrical community.

In her book Theatre $\mathcal{E}^{2}$ the Body, Collette Conroy (2010: 8) rightly points out the fact that 'theatre can offer many examples that help us to conceptualize difficult ideas, not just about performance but society and culture as well.' The critical conceptualisation of ideas about unjust relationships and unequal opportunities in society can be brought up by building elements of a temporal theatre community. The participants of the AT$L A S$ - LJUBLJANA performance thus took a step further in the political 'negotiations' over their actual status and professional aspirations for the future in relation to the individual's everyday life efforts to secure one's own bodily existence, an extremely important current issue for all generations in Slovenia. 'Despite certain differences' they stick together, and 'work together for a change in everyday life' and 'a place in society'. As such, ATLAS is an art project that critically addresses the new economic, social and political relations and their devastating impact on the vulnerable body, precarious institution and interconnectedness of social life in Europe (TURNER 2008), not only in Slovenia, where many people were forced to step into the shoes of the mythological Atlas and carry the neoliberal society on their shoulders. 


\section{Bibliography}

BERTINETTO, Alessandro. 2010. Aesthetic Distance in the Performing Arts. In Inma Álvarez, Héctor J. Pérez and Francisca Pérez-Carreño (eds.). Expression in the Performing Arts. Newcastle upon Tyne: Cambridge Scholars Publishing, 2010: 218-234.

BLAU, Herbert. 1990. The Audience. Baltimore: Johns Hopkins University Press, 1990.

BOAL, Augusto. 1979. Theatre of the Oppressed. London: Pluto Press, 1979.

CASPER, Monica J., and Lisa Jean MOORE. 2009. Missing Bodies: The Politics of Visibility. New York: New York University Press, 2009.

CONROY, Collette. 2010. Theatre $\mathcal{E}$ the Body. London/New York: Palgrave Macmillan, 2010.

MEEHAN, Emma. 2013. The Autobiographical Body: Somatic Practice and Object Relations. In Sandra Reeve (ed.). Body and Performance. Devon: Triarchy Press, 2013: 37-51.

NICHOLSON, Helen. 2005. Applied Drama: The Gift of Theatre. New York: Palgrave Macmillan, 2005.

SHAUGHNESSY, Nicola. 2012. Applying Performance: Live Art, Socially Engaged Theatre and Affective Practice. London: Palgrave Macmillan, 2012.

SHEPHERD, Simon. 2006. Theatre, Body and Pleasure. London/New York: Routledge, 2006.

SHEVTSOVA, Maria. 1989. The Sociology of the Theatre, Part One: Problems and Perspectives. New Theatre Quarterly 5 (1989): 1: 23-35.

TURNER, Bryan S. 2008. The Body and Society: Explorations in Social Theory. London: SAGE, 2008.

ZERUBAVEL, Eviatar. 1991. The Fine Line: Making Distinction in Everyday Life. The University of Chicago Press, 1991. 


\section{Tomaž Krpič}

independent researcher

tomaz.krpic@guest.arnes.si

Tomaž Krpič se zabývá sociologií poznávání prostřednictvím těla, performančními studii a problematikou diváckého těla $v$ divadle. $\vee$ současné době působí jako redaktor a výzkumník na volné noze. Publikuje knihy a studie, ve kterých se věnuje různým kulturním a společenským aspektům tělesnosti.

Tomaž Krpič is a sociologist who specialises in the body and cognition. He is interested in performance studies and the spectator's body in theatre. In the past, he has published widely on various social and cultural aspects of the human body. Currently, he works as an independent researcher and editor. 